\title{
VENCENDO AS DIFICULDADES NO ENSINO DA ESCRITA ${ }^{1}$
}

\author{
UNTANGLING SOME KNOTS IN K-8 WRITING INSTRUCTION
}

Geraldina Porto WITTER ${ }^{2}$

Shelley Peterson, professora de Educação na University of Toronto, organizou, com seus alunos, o livro intitulado "Vencendo as dificuldades no ensino da escrita", sobre o ensinar a escrever, tarefa nada fácil seja qual for o ângulo pelo qual a questão é vista.

A parte 1 do livro, composta por quatro capítulos, trata do processo de aprendizagem, que envolve professores e alunos. O primeiro capítulo, escrito por Pamela E. Van Nest, enfoca o processo de se transformar em um professor de escrita narra as mudanças que ela própria foi sofrendo e os reflexos em suas atividades em sala de aula. Usa transcrições de seu diário de atividades como exemplo dos exercícios de escrita feitos em classe, fazendo-os inicialmente duas vezes por semana e, depois, diariamente.

No capítulo seguinte, Jeanne M. Arnold e Shelley Peterson tratam da importância de conversar com os alunos sobre a escrita. Baseiam-se em suas próprias observações sobre suas conversas com os alunos e sobre as deles com eles mesmos. Os temas refletem sobre a escrita e os vários tipos de discursos escritos, sobre a importância de se permitir ao aluno falar livremente do que sabe e o do que imagina, e sobre o fato de o ensino da escrita estar presente em todo o currículo, não só no ensino da língua.
No capítulo 3, o autor Cathy Bruce começa por declarar que seu trabalho decorre de sua insatisfação pessoal quanto à revisão que fazia de seus próprios textos e das estratégias de revisão que ensinava para seus alunos. Estudou a possibilidade de trabalhar em grupos de "autores", uns revisando e discutindo os textos dos outros. Mas a literatura científica já havia demonstrado uma certa limitação nessa estratégia quando se trabalha em revisão com pessoas da mesma idade e série, embora a estratégia seja muito produtiva para os alunos elaborarem textos em cooperação. O autor buscou então trabalhar com grupos de várias idades e escolaridade; programou para um grupo seis encontros de uma hora de duração para produção e revisão de texto, e descreve o trabalho realizado com êxito. É um procedimento a ser pesquisado quando transposto para a realidade brasileira.

O último capítulo da primeira parte foi escrito por Janette Pelletier e Jennifer Lansenky. O tema é um dos mais freqüentes na produção científica: as concepções expostas pelas crianças quanto ao que seja a escrita. São apresentados os dados obtidos junto a crianças do berçário até o primeiro ano do ensino fundamental. Algumas implicações e estratégias são apontadas para os professores estimularem a escrita no pré-primário e em casa.

\footnotetext{
${ }^{1}$ Peterson, S. (Org.) (2003). Untangling some knots in K-8 Writing Instruction (viii + 139 p.). Newark: IRA.

2 Programa de Pós-Graduação em Psicologia, Centro de Ciências da Vida, Pontifícia Universidade Católica de Campinas. Av. John Boyd Dunlop, s/n, Prédio Administrativo, Jd. Ipaussurama, 13059-900, Campinas, SP, Brasil.
} 
A segunda parte do livro é composta por três capítulos que enfocam a diversidade e o ensino da escrita. O capítulo 5 , de autoria de Monika Smith e Donald S. Qi, aborda o ensino do inglês escrito para alunos em uma classe de inclusão (estudantes de outras etnias, estrangeiros etc). Vale dizer que o cerne de suas preocupações era de que modo trabalhar com alunos que estavam aprendendo inglês como segunda língua dentro de uma classe comum de falantes-escritores da língua inglesa. Esse também é um tema que já conta com uma boa bibliografia e tecnologias específicas desenvolvidas. Os autores narram sua vivência como professor e aluno, mas os que já leram sobre o assunto não encontrarão nada de novo no capítulo, embora possa ser útil como exemplo de esforço para promover integração. O tema continua no capítulo seguinte assinado por Sharon Lapken, que discute comparativamente a programação de imersão canadense e americana. Vale lembrar que as estratégias de imersão são relativamente antigas e freqüentes no ensino de língua estrangeira e implicam estabelecer condições de uso exclusivo da segunda língua por um dado período, em dada situação. São apresentados casos de alunos submetidos a esses programas e que tiveram êxito, e sugestões para seu uso em classes comuns.

Shelley Peterson assina o capítulo 7, que trata da influência das percepções do professor relativas ao modo como avalia a escrita de seus alunos em função do gênero. Retoma dados de suas pesquisas e de outros autores para discutir como isso influi no ensino e na avaliação dos meninos e meninas, e discute a necessidade de encorajar os professores a usarem medidas objetivas e critérios validados para reduzir as deturpações do professor.

A terceira parte do livro enfoca o uso de multimídia e das artes no ensino da escrita e é composta por quatro capítulos. O primeiro deles, de autoria de Joseph Allin, refere-se ao uso da tecnologia para ampliar o uso da escrita pelo aluno fora da sala de aula. Uma das propostas foi um projeto para o aluno escrever diariamente fora da escola, com impacto na sala de aula. Sua sugestão é o uso, no futuro, de monitores para ampliar essa vivência.

Carl Leggo, no capítulo 9, discute o uso da poesia como meio de ensino, indo do medo da poesia ao prazer de desfrutá-la e escrevê-la. Lembra que todo escritor é criador. Faz sugestões para o professor trabalhar a escrita desse gênero. Aliás, essa é uma preocupação que vem crescendo na atenção de docentes e pesquisadores da leitura-escrita.

No capítulo seguinte, David Booth trata da contextualização da escrita na vida do aluno. Enfoca matéria que vem sendo amplamente trabalhada e discutida desde os anos 60, destacando na sua apresentação o drama. São observações pessoais que não trazem grande contribuição.

Na mesma direção, segue o capítulo de Jill Kedersha McClay sobre a necessidade de envolver o adolescente que é escritor relutante nas atividades de escrita. Propõe a utilização de textos contemporâneos e gerados pelos próprios alunos e afirma a necessidade do uso de novas tecnologias, e lembra alguns exemplos disponíveis.

No capítulo das conclusões, a organizadora, em poucas palavras, retoma os objetivos de todos na busca de solução dos problemas do ensino da escrita. O livro é complementado por um índice de autores e um de conteúdo, facilitando a consulta. As referências bibliográficas são poucas, mas atuais e pertinentes.

Não é um livro que enfoca em profundidade a temática, mas contribui para esclarecer alguns pontos e oferecer sugestões úteis a docentes e pesquisadores. 